\title{
Globalization and Job Insecurity in Danish Firms: A Multilevel Study'
}

I Sabine Raeder ${ }^{2}$

Professor, Department of Psychology, University of Oslo, Norway

I Simon Grandjean Bamberger ${ }^{2}$

Psychologist, Department of Psychiatry, Aalborg University Hospital, Denmark

I Peter Nielsen

Associate Professor, Department of Political Science, Aalborg University, Denmark

I René Nesgaard Nielsen

Associate Professor, Department of Business and Management, Aalborg University, Denmark

I Anelia Larsen

Psychologist, Department of Psychiatry, Aalborg University Hospital, Denmark

I Anker Lund Vinding

Senior consultant, Quality Department, North Jutland Region, Aalborg, Denmark

I Kirsten Fonager

Professor, Department of Social Medicine, Aalborg University Hospital, Denmark

\section{Pia Ryom}

Psychologist, Department of Occupational Medicine, Aalborg University Hospital, Denmark

\section{Oyvind Omland}

Professor, Department of Occupational Medicine, Aalborg University Hospital, Denmark

\begin{abstract}
Globalization is on the agenda as a cause of job insecurity, but knowledge regarding the relationship between globalization, management practices, and employee job insecurity is in fact limited. This study aims to investigate this multilevel association, defining globalization by the interrelated aspects of competition, liberalization, and technological innovation, and management by offensive practices such as external collaboration, organizational change, numerical flexibility, and work intensification. Questionnaire data were collected in 2010 from 3392 employees of 569 Danish companies and analyzed with multilevel modeling. The results show that international collaboration and numerical flexibility are associated with higher job insecurity. The level of job insecurity
\end{abstract}

\footnotetext{
${ }^{1}$ You can find this text and its DOI at https://tidsskrift.dk/njwls/index.

${ }^{2}$ Corresponding authors: Sabine Raeder, sabine.raeder@psykologi.uio.no and Simon Grandjean Bamberger sigb@rn.dk.
} 
varies with occupational position, age group, and company size. Because globalization and the management of globalization are associated with employee job insecurity, companies should react in a timely way to globalization pressures: for example, by involving employees, communicating clearly, and supporting employees with lower education.

\section{KEYWORDS}

Dynamic capabilities / flexibility / globalization / job insecurity / management practices / organizational change

\section{Introduction}

he context of global deregulated markets produces substantial uncertainty and reduces the timeframe for strategic actions in many companies (Hitt et al. 1998). Given increased global competition, many companies strive to develop more dynamic, competitive, and flexible organizations (Augier \& Teece 2008; MEADOW consortium 2010; Nielsen et al. 2012). Employees are a key resource in making this process a success, but how does the ongoing ambiguity regarding the unstable future affect them? Globalization is often considered an underlying cause of increasing job insecurity (Scheve \& Slaughter 2004), but little is actually known about how the context of globalization and related management practices affect employee perception of job insecurity. The focal point of job insecurity is the perceived threat of job loss or the loss of some aspects of one's job combined with a sense of powerlessness or an inability to do anything about it (Ashford et al. 1989). The literature has either sought to explain job insecurity at a societal level, comparing political and economic systems, or from an employee perspective, focusing on organizational change or work flexibility (Ashford et al. 1989; Baillien \& De Witte 2009; Vander Elst et al. 2010). From these perspectives, employees' perception of job insecurity largely depend on their employment and their employers' economic situation (Keim et al. 2014; Shoss 2017).

Studies in strategic management have revealed that internal dynamics and management practices are largely determined by a response to developments in the external environment (Augier \& Teece 2008; MEADOW consortium 2010; Nielsen et al. 2012). When companies implement measures in response to globalization pressures (Augier $\&$ Teece 2008), they can attenuate or increase their employees' perception of job insecurity (Oreg \& Sverdlik 2011). However, research has paid little attention to explaining dynamic capabilities and the resulting superior firm performance with employees' behaviors and attitudes, although these shape firm performance to a large degree (Abell et al. 2008; Felin et al. 2015). Research has thus yet not examined how a company's external context of globalization and the management practices implemented in companies affect employees' perceptions of job insecurity (Shoss 2017).

The present study analyzes the association between job insecurity as perceived by employees and their employers' view of globalization and management efforts in response to external pressures. We build on the dynamic capabilities framework for investigating management efforts because this framework has been previously related to changing global environments (Augier \& Teece 2008; MEADOW consortium 2010; Nielsen et al. 2012). Dynamic capabilities are a strategic approach for management's handling and coping with changing, unpredictable environments by continuously 
renewing routines and reallocating resources (Johnson et al. 2009; Teece 2007). To enhance their dynamic capabilities in response to the demands of globalization, companies can design and adapt their organizations to increase organizational flexibility.

We decided to explore relations between globalization and related management practices and job insecurity with a multilevel approach, capturing both the employer and the employee perspective. We focus on affective job insecurity first, because it is considered more important in the context of flexicurity than cognitive job insecurity (Anderson \& Pontusson 2007; Berglund et al. 2014). While cognitive job insecurity refers to the possibility of losing one's job, affective job insecurity denotes the emotional experience of a potential job loss. Affective job insecurity better reflects the context of high labor market insecurity and employment security, which denotes the chances of finding employment in the labor market and protection for employed workers and support for unemployed workers. Second, affective job insecurity has been examined in relation to well-being (Jiang \& Probst 2016) and was thus implemented in the Copenhagen Psychosocial Questionnaire (COPSOQ, Pejtersen et al. 2010) that was used in this study. We assume that employees perceive job insecurity both due to company-specific pressures of globalization and specific management practices. Our empirical analyses are based on cross-sectional multilevel data collected in 2010 among employers and their employees in the Danish private sector, in which companies operate in an open economy with limited market growth. Our data cover a period with recession and economic crises, following the financial crisis of 2008.

Our study extends existing knowledge on dynamic capabilities by investigating consequences for employees, particularly for their job insecurity (Abell et al. 2008; Felin et al. 2015). Exploring such consequences allows researchers to assess whether and how management practices enhance organizational competitiveness. Furthermore, this study contributes to extant research by explaining job insecurity in light of company-specific pressures of globalization and the management practices utilized by the organization (Quinlan \& Bohle 2009). It extends existing research that has compared job insecurity due to globalization across countries or that has examined the effects of the employees' view on organizational change or work flexibility on job insecurity (Anderson \& Pontusson 2007; Mau et al. 2012). It allows us to differentiate between external pressures due to globalization and the specific practices used in the companies and to understand the consequences of each of these factors for employees. Our choice of a multilevel design that links employer and employee data and considers globalization exposure variables as well as organizational variables further elaborates on the contextualization of job insecurity (Ashford et al. 1989; Baillien \& De Witte 2009; Vander Elst et al. 2010). The study thus clarifies the often-assumed relationship between globalization and job insecurity in the context of business organizations.

\section{The Danish context of flexicurity}

Flexicurity, developed in the Netherlands and Denmark, consists of three ingredients: a flexible labor market with low dismissal protection for employees, generous employment benefits, and lifelong learning policies (Bredgaard \& Madsen 2018). The Danish flexicurity policy thus promotes employment security and employability instead of job security. This particular focus of the Danish employment system is also visible in 
the fact that job insecurity is lower in Denmark than in other countries (Anderson $\&$ Pontusson 2007; Green 2004). As a consequence of the financial crisis, however, the unemployment rate in Denmark rose from 3.2\% in 2008 to $7.8 \%$ in 2012 but still remained below the European average (Bredgaard \& Madsen 2018; OECD 2016). This economic development put pressure on the Danish flexicurity model. The pressure was increased by policy reforms on the security side of the model, reducing the duration of unemployment insurance benefits to a two-year period. This reduction took place in parallel with a gradual reduction in the compensation rate of unemployment benefits (Bredgaard \& Madsen 2018). The reform created an obvious shift of balance between flexibility and security in the model, and 50,000-70,000 unemployed people exhausted their unemployment benefits. The flexicurity system failed to prevent the consequences of the financial crisis for employment, but the employment situation recovered quickly after the crisis had faded away. In a comparison of employment systems of different European countries, the combination of high flexibility and security was found to attenuate affective job insecurity; thus, the Danish flexicurity model was perceived to be preferable to other combinations of flexibility and security (Probst $\&$ Jiang 2017).

\section{Job insecurity in the context of globalization}

In the era of increasing globalization with a deregulated market economy, job insecurity is regarded as a chronic condition affecting the general workforce (Scott 2004). Globalization is defined as an increase in global connectivity within economic, technological, and cultural domains, along with expansions of trade, finance, labor mobility, and production (Philips \& Eamets 2007; Spiegel et al. 2004). Three interrelated processes have been identified as core aspects of globalization (Mills 2009; Nielsen \& Lundvall 2006; Nielsen et al. 2012): (1) Liberalization, deregulation, and the opening of new markets have created a multitude of cross-border markets for companies. (2) Technological innovation made this economically viable due to falling transport prices, global distribution of the value chain, and rapid developments in communication. (3) This led to increased levels of competition for companies that compete with companies around the world for market shares. At a societal level, economic instabilities of globalization most likely affect employment insecurity, that is, the probability of finding another job with more or less equivalent characteristics (Anderson \& Pontusson 2007; Chung \& van Oorschot 2011). At the company level, the three processes of globalization can be perceived as threatening employees' jobs, thus creating job insecurity.

First, liberalization and deregulation further lead to the integration of national economies into a single world market. While growth is slow in developed countries, fierce competition from emerging and developing countries places pressure on companies in developed countries (Mastrostefano et al. 2009). Liberalization and deregulation give companies access to other countries' markets but at the same time allow foreign companies to access the company's local market (Philips \& Eamets 2007). The growing economic interdependence across borders makes the local economy vulnerable to international economic instability, such as the global financial crisis of 2008 (Zaharia et al. 2011). We thus assume that employees perceive higher job insecurity if their company is operating in a context of liberalization and deregulation. 
Second, technological innovation has been the pivotal catalyst in the rapid development of globalization, transcending previous boundaries of information, communication, and transport (Archibugi \& Michie 1995). This development has evolved at several levels. Innovation in communication and transport has enabled a rapid transfer of work between old and new industrialized countries. The industrialized countries underwent structural changes from manufacturing toward the service industries but, at the same time, a new generation of manufacturing companies emerged. Technological innovation has allowed many standard repetitive functions to be replaced by machines and sophisticated robots, which boost the new manufacturing concept. The technological revolution has thus influenced internal processes in companies because it demands subsequent task reallocation actions and organizational changes (Nielsen et al. 2008). These developments occurring at different levels increase employees' perception of job insecurity if their industry or organization is affected.

Third, growing and frequently changing market opportunities and threats directly or indirectly induce competition in price, quality, and innovation for individual companies (Hitt et al. 1998). Competition not only drives efficiency, innovation, and absorption of new knowledge but also bears the risk of failing to achieve these targets, potentially resulting in downsizing or the transfer of work to other countries (Lundvall 2002). Hence, we assume that employees in firms in highly competitive business environments perceive their jobs as less secure.

Due to pressures of globalization in the form of liberalization, continuous technological innovation, and growing competition among companies, many employees who formerly perceived their positions in the organization as safe are now experiencing uncertainty (Scheve \& Slaughter 2004). We thus expect employees to increasingly view their jobs as insecure, specifically in relation to globalization dimensions. Related to globalization dimensions, we posit the following hypothesis:

Hypothesis 1: Liberalization (a), competition (b), and technological innovation (c) are associated with higher levels of job insecurity in companies.

\section{Management practices to address globalization}

Advancing a company's dynamic capabilities implies the continuous and proactive use of key practices appropriate for surviving and succeeding in a globalized economy characterized by rapid change (Augier \& Teece 2008; Eisenhardt \& Martin 2000). Dynamic capabilities are theoretically founded on the resource-based view of the firm that emphasizes the importance of proactively developing firm-specific resources to promote competitive advantages (Peteraf 1993; Wernerfelt 1984). This perspective of conscious resource development and allocation has been supplemented by the framework of dynamic capabilities that stresses the importance of being continuously able to renew and reallocate resources to cope with the changing context (Johnson et al. 2009; Teece 2007). In a globalized context, companies strive to enhance their dynamic capabilities through management practices that aim (1) to expand organizational knowledge, (2) transform organizational structure to meet current pressure, or (3) increase the company's flexibility (Nielsen et al. 2012; Teece et al. 1997; Wright et al. 2001). This study comprises four key practices derived from the theory of dynamic capabilities that 
complement the pressure of globalization and presumably affect the employees' perception of job insecurity because proactive transformations in companies might either result in redundancies or the enhancement of the employees' value on the labor market. The first two objectives of dynamic capabilities are captured with one management practice each, while the third goal is covered with two management practices. These practices are selected from a larger pool of potential practices because the framework of dynamic capabilities does not determine the practices to be used to maintain or enhance the firm's competitiveness in the context of globalization (Schilke et al. 2018; Sirmon et al. 2007).

Any changes in the organization related to knowledge, structure, or flexibility require that employees adapt to new demands. While some management practices demand more flexible skills, others might endanger employment and put jobs at risk. Current research on dynamic capabilities has, however, not considered how capabilities affect employees or how they are perceived by employees (Abell et al. 2008; Schilke et al. 2018). Linking management practices to job insecurity thus helps further explore the relationship between dynamic capabilities and firm competitiveness because of the known relationship between job insecurity and employee performance that further leads to firm performance (Abell et al. 2008; Shoss 2017).

Capabilities demand organizational knowledge that can be expanded through collaboration with other companies across national borders. In terms of dynamic capabilities, companies develop valuable skills and competences that competitors cannot easily copy (Eisenhardt \& Martin 2000). The current technological development generates a growing flow of information that increases the need for interorganizational relationships to manage and convert the information for product development and innovations (Cegarra-Navarro \& Dewhurst 2007; Lundvall 2002). Access to knowledge through international partners can provide access to technological capabilities embedded in partner firms as well as to market conditions and opportunities embedded in the partner's national environment. By merging separate home-based technological capabilities, international collaboration can create unique and powerful competitive opportunities (Vinding $\&$ Drejer 2006). However, these types of collaborations do not come without risk or costs. The companies are potentially revealing key aspects of their products and services, and this leaves them vulnerable and more dependent on outside forces (Bruce et al. 1995). Employees may see interenterprise collaboration as the first step in the direction of outsourcing or foreign ownership, which may increase their job insecurity (Dill \& Jirjahn 2016). We thus suggest that job insecurity is related to international collaboration:

Hypothesis 2: The company's use of external collaborators at the international level is associated with a higher level of job insecurity in companies.

Organizations transform their organizational structure to improve cooperation and coordination in the organization, to enhance efficiency in all processes, to facilitate the development of new products and services and thus to increase the adaptive, dynamic capacity in response to global competition (Lundvall 2002). Although organizational changes are frequently implemented to maintain or increase efficiency and help organizations survive, employees often react with critical attitudes and behavior, among them the perception of job insecurity (Oreg et al. 2011). In ongoing organizational change, employees are afraid that their job might be redundant due to the efforts to design the organization toward higher efficiency (Ashford et al. 1989; Baillien \&

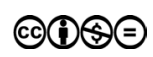


De Witte 2009; Probst 2003). Earlier research has concentrated on studying employees' experiences of organizational changes but left the organizational view on the intentional use of changes unconsidered. Although a closer relation can be assumed between employees' experiences of organizational change and job insecurity, any use of change measures in the organization might still lead to job insecurity. We thus aim to explore the relationship between the organizational use of change and job insecurity with the following hypothesis:

Hypothesis 3: The use of organizational change is related to a higher level of job insecurity in companies.

Numerical flexibility is a human resource strategy to remain competitive and costefficient within the flexicurity approach institutionalized in Denmark (Bredgaard et al. 2006). The flexibility permitted by the collective agreements and legal regulations allows companies to adapt their workforce to business needs through recruitment and dismissal, adjustment of working hours (overtime, flextime, and distribution), and use of temporary employment (Burchell et al. 2001). Companies thus customize their workforce through numerical flexibility via the external and internal labor market (Schief 2010). While the practice of recruiting and dismissing employees immediately indicates a lack of job security (Ellonen \& Nätti 2015; Gallie et al. 2017; Keim et al. 2014; Maertz et al. 2010), temporary and part-time employment does not necessarily lead to job loss. However, several studies have shown that temporary and part-time employees perceive higher job insecurity compared to permanent and full-time contract employees (Burgoon \& Dekker 2010; Vander Elst et al. 2010). Even when temporary workers are hired for the same occupations in the same company, permanent employees feel that their jobs are less secure (Banerjee et al. 2012). Based on these results, we assume that employees perceive higher job insecurity in the context of numerical flexibility:

Hypothesis 4: The use of numerical flexibility increases job insecurity among employees of companies.

An alternative option to increase a company's flexibility is to motivate employees to work more efficiently, resulting in work intensification (Burchell et al. 2001; Green 2004). Closer adaptation of working hours to workload means that fewer employees are needed to provide the same services. Work intensification can manifest itself in more work hours or greater work effort during work time (Green 2001). When qualified or managerial positions are reduced, however, the staff must perform a broader range of tasks with more responsibility and autonomy (Hassard \& Morris 2017). Work intensification may arise as a result of changes such as the introduction of lean techniques, the implementation of new technology, flexible working practices, and downsizing or working time reductions without new hires (Burchell et al. 2001; Green 2004; Kelliher \& Anderson 2010; MEADOW consortium 2010). Earlier research has explored the relationship between work intensification and job insecurity in a correlational form, reporting positive correlations (Boxall \& Macky 2014). Work intensification implemented in a company can thus also increase the level of job insecurity since employees will be worried that they might fail to meet the demands of the work intensification and might lose their job (Burchell et al. 2001). We hypothesize the following: 
Hypothesis 5: Work intensification is associated with a higher level of job insecurity in companies.

\section{Methods}

\section{Research context and sample}

Matched questionnaire data referring to the time period of 2007-2009 were collected among employers and their employees in the Danish private sector in 2010. The use of data from companies and their employees allowed us to avoid problems of common method variance because a systematic bias due to the use of self-report data cannot be expected (Podsakoff et al. 2012).

\section{Company sample}

The company sample originates from the study 'Danish Innovation System: Comparative analysis of challenges, strengths and bottlenecks' (DISKO) (Gjerding 1997) that collected data in four rounds from 1996 to 2006 from employer representatives in private firms with more than 10 employees. The 1770 companies that had completed the DISKO study in 2006 were used as a basis for the company sample in the present study. In 2010, 254 of these companies were either closed or listed as having fewer than 10 employees and another 86 companies requested removal from the study. Unique login information for the web questionnaire was sent to a line or an HR manager in 1430 companies. The companies received three reminders. A total of 601 companies answered the survey (response rate of $42 \%$ ), but 32 had to be removed due to missing values on key variables or lack of employee responses. Finally, 569 companies were included in the sample. Five different industries (1. Production, quarrying, and supply, 2. Construction and maintenance, 3 . Trade and transport, 4. Information, communication, finance, and insurance, 5. Real estate, rental business, service, and other) and three different company sizes $(<50,50-99,>100)$ were covered by the sample. The sample contained more small-size $(\mathrm{n}=217)$ and large-size $(\mathrm{n}=201)$ companies than mediumsized ones $(\mathrm{n}=151)$.

\section{Employee sample}

The employee sample consisted of 3392 employees of the 569 companies. A total of 6626 employees were contacted by letter and invited to answer a web survey, and 3651 employees provided data (response rate of $55 \%$ ). Of these, 173 were excluded because they were not employed by the company in the time period 2007-2009, and 86 were excluded due to missing company data, resulting in a final response rate of $52 \%$.

The employees contacted were sampled from the collectivity of all salary earners $(\mathrm{n}=79,431)$ in the responding companies from Statistics Denmark's registry data. To avoid overrepresentation of employees from larger companies, a weighted sampling strategy helped select a larger percentage of employees from smaller companies (depending 
on the size of the company, up to 12 employees were selected for participation). If more than $50 \%$ of the companies within one of the combinations of industry and firm size failed to respond, more employees were sampled from responding companies within that category. Due to this semiweighted sampling design, the percentage of employees from the total sample in each of the combinations corresponds to the percentage of companies sampled.

Employees received three reminders. Reasons for dropout were that employees could not be contacted by phone $(n=1818)$, refused to participate $(n=599)$, found this survey not relevant $(\mathrm{n}=558)$, or were not available due to language barriers, sickness, or travel. The final sample of 3392 employees consisted of $68 \%$ men and $32 \%$ women aged between 16 and 82 years (median 48 years; Table 1 ).

\section{Measures}

The dependent variable job insecurity was measured at the employee level, while the independent variables of globalization and management practices were measured at the organizational level (all items in Table 2).

Table I Means and standard deviations of job insecurity for different groups in the employee sample (Level I and 2)

\begin{tabular}{lccc}
\hline & n & M & SD \\
\hline All & 3392 & 27.32 & 19.9 \\
Gender & & & \\
Men & 2296 & 26.43 & 19.18 \\
Women & 1096 & 29.20 & 21.22 \\
Age groups & & & \\
I6-40 & 800 & 25.51 & 19.16 \\
$41-47$ & 839 & 28.56 & 19.55 \\
$48-54$ & 835 & 29.53 & 20.29 \\
$55+$ & 918 & 25.77 & 20.25 \\
Occupational position & & & \\
White-collar & 657 & 22.47 & 16.66 \\
Blue-collar & 1947 & 26.83 & 19.32 \\
Unskilled workers & 788 & 32.58 & 22.46 \\
Company size & & & \\
$0-49$ & 1154 & 24.62 & 19.11 \\
$50-99$ & 929 & 27.36 & 19.93 \\
I00+ & 1309 & 29.68 & 20.28 \\
\hline
\end{tabular}


Table 2 Scales and items used in this study

\begin{tabular}{|c|c|}
\hline Scales & Items \\
\hline Liberalization & $\begin{array}{l}\text { To what extent has liberalization of international trade had an effect on the develop- } \\
\text { ment of the company's competitive conditions in the period 2007-2009: } \\
\text { 1. On product or service prices } \\
\text { 2. On product or service quality } \\
\text { 3. On development of new products or services }\end{array}$ \\
\hline Competition & $\begin{array}{l}\text { At present, to what extent is the company experiencing competition in the following } \\
\text { 1. Product or service prices } \\
\text { 2. Product or service quality } \\
\text { 3. Development of new products or services }\end{array}$ \\
\hline Technology & $\begin{array}{l}\text { To what extent has the overall technology development in the industry had an influ- } \\
\text { ence on the development of the company's competitive conditions in the period } \\
\text { 2007-2009: } \\
\text { I. On product or service prices } \\
\text { 2. On product or service quality } \\
\text { 3. On development of new products or services }\end{array}$ \\
\hline $\begin{array}{l}\text { International } \\
\text { collaboration }\end{array}$ & $\begin{array}{l}\text { To what extent has the company cooperated with the following partners regarding } \\
\text { product and/or service development in 2007-2009? } \\
\text { I. Foreign customers } \\
\text { 2. Foreign suppliers }\end{array}$ \\
\hline $\begin{array}{l}\text { Organizational } \\
\text { change }\end{array}$ & $\begin{array}{l}\text { Have organizational changes aimed to strengthen: } \\
\text { 1. Efficiency in daily operations } \\
\text { 2. Cooperation and coordination across the organization } \\
\text { 3. The ability to adapt to more changing environments } \\
\text { 4. The ability to continuously develop new products/services } \\
\text { 5. The ability to continuously strengthen and renew the company's knowledge } \\
\text { and know-how } \\
\text { 6. Quality and customer service }\end{array}$ \\
\hline $\begin{array}{l}\text { Numerical } \\
\text { flexibility }\end{array}$ & $\begin{array}{l}\text { Does the company use one or more of the following options to customize the staff- } \\
\text { ing resources to business needs? } \\
\text { 1. Recruitment and dismissal } \\
\text { 2. Personnel rotation between different work tasks } \\
\text { 3. Adjustment of working hours (overtime, flextime, distribution) } \\
\text { 4. Changes in work tempo } \\
\text { 5. Temporary appointments } \\
\text { 6. Agency appointments } \\
\text { 7. Part-time work }\end{array}$ \\
\hline $\begin{array}{l}\text { Work } \\
\text { intensification }\end{array}$ & $\begin{array}{l}\text { Has the work content changed in the period } 2007-2009 \text { in the direction of: } \\
\text { I. Increased autonomy and responsibility } \\
\text { 2. Increased technical/professional demands } \\
\text { 3. Increased knowledge content } \\
\text { 4. Increased interdisciplinary collaboration } \\
\text { 5. Demand for increased labor productivity }\end{array}$ \\
\hline
\end{tabular}




\begin{tabular}{lc}
\hline Scales & Items \\
\hline Job insecurity (II) & I. Are you worried about new technology making you redundant? \\
& 2. Are you worried about it being difficult for you to find another job if you \\
become unemployed? \\
3. Are you worried about being transferred to another job against your will? \\
4. Are you worried about being laid off because management is moving pro- \\
duction to another country or to another company? \\
5. Are you worried about losing your job because your company cannot sur- \\
vive due to international competition?
\end{tabular}

Note. The job insecurity items III, JI2, and II3 stem from the Copenhagen Psychosocial Questionnaire (COPSOQ; Pejtersen et al. 20 I0). Items 114 and $J 15$ were specifically designed for this study.

\section{Dependent variable (employee sample)}

Affective job insecurity was measured with three items (JI1, JI2, and JI3) from the Copenhagen Psychosocial Questionnaire (COPSOQ; Pejtersen et al. 2010). Two items of operational relevance to threats of job loss due to globalization were specifically designed for this study (JI4 and JI5). The wording of the two new items is aligned with the wording of the first item of the COPSOQ questionnaire. This measure of job insecurity thus focuses on affective job insecurity in the context of globalization. The respondents were asked to indicate the degree to which they agreed or disagreed with the statements on a five-point Likert scale $(1=$ to a very large extent degree, $4=$ to a very small extent). As in the COPSOQ scale, the values were transformed to a scale of 0-100, with 100 representing the highest degree of job insecurity. Cronbach's alpha for this scale was 0.81 and hence exceeds the reliability of the original COPSOQ scale (Cronbach's alpha $=0.77$, Pejtersen et al. 2010).

\section{Independent variables (company sample)}

Globalization was mainly measured with items developed for this study based on the OECD Oslo Manual (Organisation for Economic Co-operation and Development \& Statistical Office of the European Communities 1997) and the MEADOW guidelines (MEADOW consortium 2010), while management practices were with a few exceptions measured with scales from the DISKO study (Timmermans 2008; Vinding \& Reichstein 2003). For most of the scales, participants provided responses on four-point Likert scales, either assessing the degree or the importance (see below). Table 3 in the data analysis section shows the descriptive statistics, correlations, and internal consistencies of study variables at Level 2.

Globalization was measured with three scales tapping the companies' exposure to liberalization, competition, and technology, which were mainly designed for this study. Each of the three scales contains three items for assessing competition, liberalization, or technology, with a focus on products and services ( $1=$ not at all, $4=$ to a large degree). Furthermore, the competition scale contains two items from the DISKO questionnaire, capturing competition exposure on the Danish or world market $(1=$ not at all, $4=$ to a large degree). 
Table 3 Descriptive statistics and correlations of study variables (Level 2)

\begin{tabular}{lccccccccc}
\hline & $\mathbf{M}$ & $\mathbf{S D}$ & $\mathbf{I}$ & $\mathbf{2}$ & $\mathbf{3}$ & $\mathbf{4}$ & $\mathbf{5}$ & $\mathbf{6}$ & $\mathbf{7}$ \\
\hline I. Liberalization & 1.61 & 1.55 & $(0.94)$ & & & & & & \\
2. Competition & 3.17 & 1.23 & $0.35 * * *$ & $(0.79)$ & & & & & \\
3. Technology & 2.12 & 1.41 & $0.42 * * *$ & $0.45 * * *$ & $(0.92)$ & & & & \\
4. International collaboration & 1.70 & 1.52 & $0.34 * * *$ & $0.21 * * *$ & $0.22 * * *$ & $(0.69)$ & & & \\
5. Organizational change & 2.44 & 1.82 & 0.07 & $0.19 * * *$ & $0.19 * * *$ & $0.26 * * *$ & $(0.95)$ & & \\
6. Numerical flexibility & 2.33 & 0.87 & 0.10 & $0.13^{*}$ & $0.16 * *$ & $0.18 * * *$ & $0.28 * * *$ & $(0.71)$ & \\
7. Work intensification & 2.12 & 1.54 & 0.09 & $0.16 * *$ & $0.22 * * *$ & $0.23 * * *$ & $0.36 * * *$ & $0.27 * * *$ & $(0.87)$ \\
\hline
\end{tabular}

Note. Cronbach's alphas are reported in brackets on the diagonal. ${ }^{*} \mathrm{p}<0.05 ;{ }^{* *} \mathrm{p}<0.01 ;,{ }^{* * *} \mathrm{p}<0.001$.

Management practices were examined with four scales measuring international collaboration, organizational change, numerical flexibility, and work intensification. International collaboration was originally measured with one item regarding cooperation with foreign customers. Two additional items were developed for this study concerning cooperation with foreign suppliers (answered on a scale from $1=$ not at all, $4=$ to a large degree). The use of organizational change was measured with six items investigating whether changes were targeted to increase efficiency and support innovation ( $1=$ not at all, 4 = to a large degree). Numerical flexibility was examined with seven items covering several forms of adjusting staffing to business requirements $(1=$ not at all, $4=$ to a large degree). Work intensification was measured with five items by tapping into increased demands and responsibility for white-collar workers, blue-collar workers, and other employees. Respondents indicated whether the type of work intensification applied to each group of employees $(0=$ no, $1=$ yes $)$. This measure thus captures several forms of increased demands that affect work intensification for different levels of employees (e.g., a broader range of tasks with more responsibility for managers, Hassard \& Morris 2017). Responses were summed for each type of work intensification, resulting in values between 0 and 3 .

\section{Control variables and variables for random slope}

We control for the potential influence of company size at the organizational level and for gender, age, and occupational position at the employee level (Table 4). Gender, age, and occupational position were included as control variables because earlier studies had shown that job insecurity differs according to these variables (Baillien \& De Witte 2009; Näswall \& De Witte 2003). The employee-level variables were used to test random slopes because the relationship between globalization and management practices and job insecurity could vary between companies according to the composition of staff within each organization.

\section{Data analysis}

Prior to the analysis, all predictors were standardized. Data were analyzed by means of multilevel modeling to account for the nested data structure (Hox 2010) with employees 


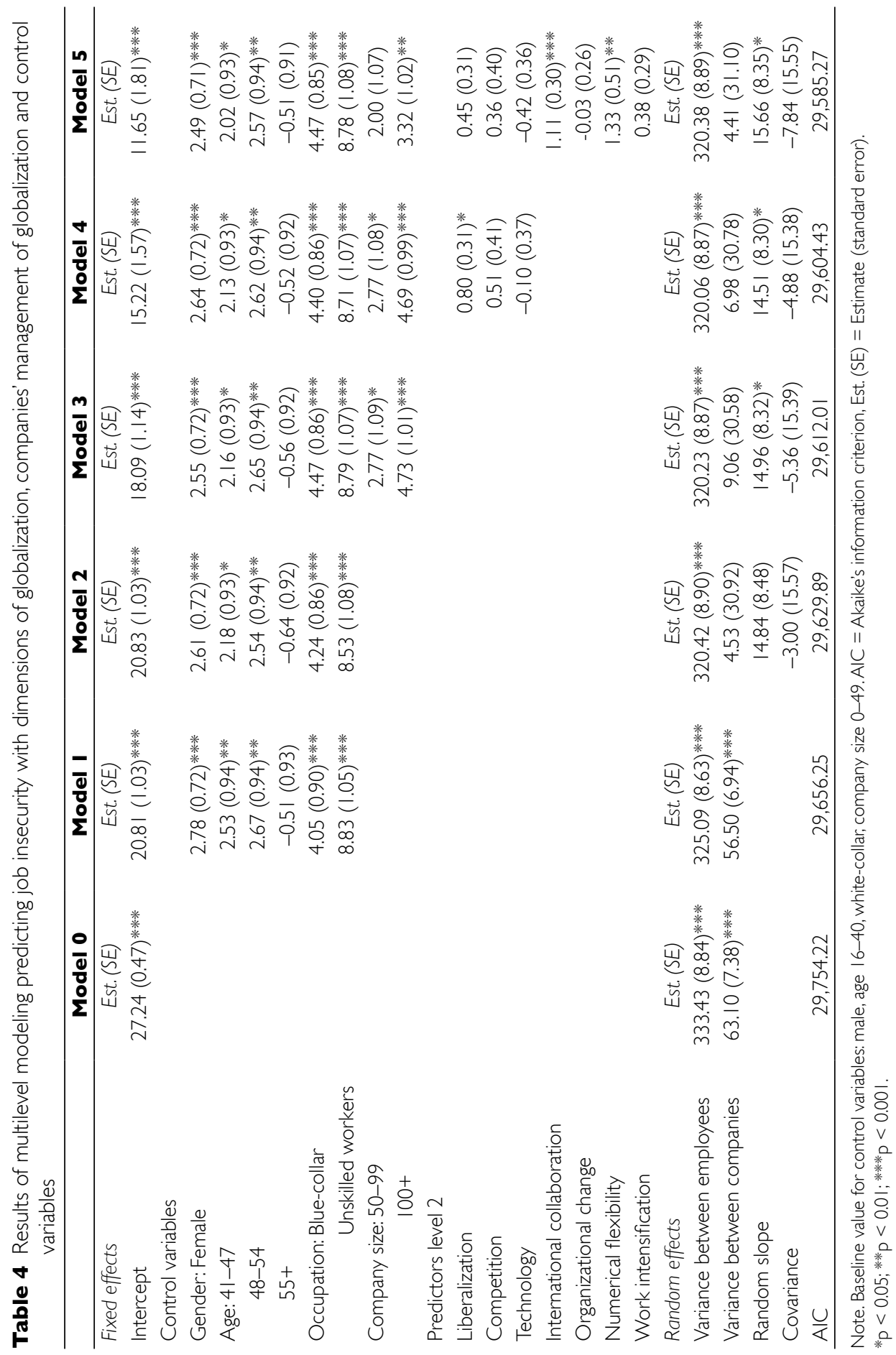


(Level 1) nested in companies (Level 2). The analysis was performed in six steps with STATA (Table 4). The first model (Model 0) served to investigate the partitioning of variance between the levels. Of the total unexplained variance, $84 \%$ resided between employees and $16 \%$ between companies, resulting in an intraclass coefficient (ICC) of 0.16. In Model 1, the control variables at Level 1 gender, age, and occupation were included. We then tested whether one of the Level 1 variables could be used as a random slope to allow the slopes in each company to vary freely. The best results were found for occupation (Model 2). In Model 3, the control variable at Level 2 company size was added. In Model 4, the three globalization predictors were investigated. In the final model (Model 5), we added the four management practices: national and international collaboration, organizational change, numerical flexibility, and work intensification. Model fit was assessed with Akaike's Information Criterion (AIC) on a smaller-is-better basis.

\section{Results}

The descriptive statistics and correlations of employee and organizational level variables are shown in separate tables to avoid aggregation or disaggregation of data (Tables 1 and 3). All control variables at the employee level are categorical, and Table 1 presents the means and standard deviations of job insecurity for each category.

Hypothesis 1 tests whether the globalization-related predictors have a positive effect on job insecurity. The predictors liberalization (H1a), competition (H1b), and technology (H1c) do not show an effect on job insecurity (Table 4), and Hypotheses 1a, 1b, and $1 \mathrm{c}$ are not supported. Hypotheses 2-5 investigate the relationships between the four management practices and job insecurity. In Hypothesis 2, we assume that company use of international collaborations increases job insecurity. International collaboration is related to job insecurity, and we thus find support for Hypothesis 2. In Hypothesis 3, we state that organizational change increases job insecurity. The use of organizational change is not significantly related to job insecurity, and thus Hypothesis 3 is not supported. Hypothesis 4 tests the enhancing effect of numerical flexibility on job insecurity. The use of numerical flexibility shows a positive estimate in support of Hypothesis 4. In Hypothesis 5, we examine the positive relation between work intensification and job insecurity. This relation is not significant, and Hypothesis 5 is not supported.

The control variables at the employee level and at the company level are statistically significant and explain variance. Specifically, women perceive higher job insecurity than men, employees aged 41-54 years experience higher job insecurity than younger employees, and blue-collar or unskilled workers worry more about their job than white-collar employees. The use of occupational position as a random slope improves the quality and explanatory power of the model, indicating that job insecurity is higher in organizations with a higher proportion of unskilled or blue-collar workers. No such effect is found for gender or age. Employees in firms with more than 100 employees report higher job insecurity. In particular, the estimates of occupational position are comparably large, indicating that occupations clearly affect the perception of job insecurity.

The final model (Model 5) shows the best fit indicated by the lowest AIC, but differences between Models 3, 4 and 5 are small. Compared to Model 0, Model 5 explains 43\% of the variance between companies calculated from the relation between unexplained 
variance at Level 2 in Model $0(=63.10)$ and unexplained variance at Level 2 in Model 5 (= variance between companies $+2 *$ covariance + variance random slope $=$ 35.75). The unexplained variance in the random slopes remains more or less stable throughout the analysis, but the use of the variable occupational position as a random slope clearly reduces the unexplained variance between companies (random intercept) from Model 1 to Model 2. The variance between companies (random intercept) increases when the organizational control variables are introduced but is mostly explained by the predictors. In addition, the random slope with occupational position plays an important role in explaining variance, that is, the relationships between independent and dependent variables also vary according to occupations.

\section{Discussion}

In this study, we probe the influence of globalization and company practices to manage globalization on employees' job insecurity. The globalization variables are not related to job insecurity. From the four management variables, only international collaboration and numerical flexibility are linked to a higher level of job insecurity. Individually perceived job insecurity varies largely with company size, occupation, age group, and gender.

The results show that employees' perception of job insecurity is more strongly affected by the four management practices than by globalization. The use of management practices is only partly related to the three dimensions of globalization, indicating that some companies implement these practices for reasons other than globalization (Table 3). International collaboration with customers and suppliers is associated with higher job insecurity. The negative influence of international collaboration can be related to the fear of outsourcing or similar activities (Bredgaard et al. 2006). The more that a company is active in other countries, the more likely it is that the company moves production and jobs out of the country if costs increase (Davis-Blake \& Broschak 2009; Maertz et al. 2010). The use of numerical flexibility is associated with higher job insecurity among the companies' staff, consistent with earlier research that investigated contingency labor (Banerjee et al. 2012; Vander Elst et al. 2010) and downsizing (Keim et al. 2014). This result probably occurs because such forms of flexibility entail a higher risk of job loss, especially in a period with emerging economic recession.

Contrary to prior studies with a focus on the employees' perspective (Baillien \& De Witte 2009), we fail to find an influence of the use of organizational changes on job insecurity. These results might be because the use of changes aims to enhance efficiency and innovation, thus posing higher demands on workers without endangering the security of jobs through reduction of staff or work time. The lack of relation between work intensification and job insecurity, which were previously found to be related (Boxall \& Macky 2014; Burchell et al. 2001), can also be explained by the goal of increasing efficiency and innovation without consequences for employment. In measuring work intensification, we adhere to McCann, Hassard, and Morris (2010) and Hassard and Morris (2017), who consider higher responsibility and autonomy as a feature of work intensification in jobs that require higher qualifications. This measure represents the fact that intensification in qualified jobs leads to fewer people having to fulfill a broader range of work tasks, but the results are thus not fully comparable to studies that restricted work intensification to higher quantitative demands (Boxall \& Macky 2014). 
Occupational position was found to be an influential variable with higher job insecurity for unskilled and blue-collar workers compared to white-collar workers. In general, unskilled and blue-collar workers have access to fewer learning opportunities (Standing 1997) and are more exposed to numerical flexibility than white-collar workers (Nielsen 2006). However, job insecurity has traditionally been lower in Denmark than in other countries (Anderson \& Pontusson 2007; Green 2004). Denmark is known to have a flexible labor market in which it is easy to hire and fire people while a high level of social security and an active labor market policy collectively provide a safety blanket (Jensen 2011).

In contrast to research investigating job insecurity at the societal level (Anderson \& Pontusson 2007; Mau et al. 2012), this study fails to find support for the effect of globalization at the company level. In our sample, differences in affective job insecurity between types of employees and companies exceed the effects of globalization, thus masking the influence of globalization. Furthermore, globalization might be perceived as less of a threat due to Denmark's position in innovation (Hollanders \& Es-Sadiki 2013). Although this advantage means that many demands are posed on companies and employees alike, it also puts the country in a position of comparative advantage on the world market.

The research results contribute to the body of research on the dynamic capabilities framework by showing that implemented management practices can lead to negative outcomes among employees. While management practices serve to maintain and enhance competitiveness (Schilke et al. 2018), the results indicate that this goal might not be accomplished for all management practices. Two of the four practices result in a higher level of job insecurity. Earlier research has found that job insecurity is negatively related to employee performance that to a large degree determines organizational productivity (Jackson et al. 2014; Shoss 2017). Hence, some of the management practices implemented to adapt the organization to internal and external demands potentially fail to support organizational competitiveness. Fortunately, the level of job insecurity is rather low in this Danish sample, thus lowering any risks for performance outcomes.

Our study extends existing research on predictors of job insecurity. We demonstrate that the use of management practices only leads to perceiving job insecurity if they imply an immediate risk of job loss. While international collaboration and flexibility endanger jobs in Denmark, organizational change and work intensification primarily aim at increasing efficiency at work. Globalization at the company level fails to relate to the employees' perception of job insecurity while not being strongly correlated with the use of management practices. Overall, the four management practices explained the employees' perception of job insecurity better than the three indicators of globalization.

\section{Limitations and future research}

The generalizability of our study is limited by certain design choices. Organizational participants were invited to respond to the questionnaire with regard to the years 20072009. This time period was chosen to provide coherent and comparable information on activities carried out by companies (MEADOW consortium 2010). We were, however, not able to control whether the participants' data might have been biased through events that had happened since. Furthermore, data were obtained during the breakout 
of the financial crisis, which might have added to the general level of job insecurity (Scott 2004). While the increased focus on the financial crisis could lead to a potential overestimation of job insecurity, the fact that the unemployment rate has been steadily rising during the entire period documents that there are good reasons for heightened feelings of job insecurity (Statistics Denmark 2010). Due to our weighted sampling strategy, responses from smaller firms were overrepresented in the study sample. The nonresponders are not skewed since the number does not differ substantially across industry types or company sizes. The results should therefore be generalized to all types of organizations and other countries with caution. Especially for international comparisons, further research is needed.

\section{Consequences for practice}

The results of this study show that management practices affect employees' perception of job insecurity. A feeling of uncertainty can deplete employees' motivation and commitment and thus diminish work performance, on which the company relies for remaining innovative and competitive (Jiang \& Lavaysse 2018). To mitigate negative consequences, potential changes due to globalization and newly implemented management practices should be communicated early, and managers and employees should be supported in adapting to ongoing changes. Employers could also provide information about their perception of job insecurity to reduce employees' job insecurity if their job is not endangered. Additional support should be provided to employees with a lower level of education and competencies because they lack a level of training and education protecting them from negative consequences of job loss and unemployment.

\section{Conclusion}

In this study, we explored the influence of globalization and company practices to manage globalization on the employees' perception of job insecurity. The use of linked employer and employee data allowed us to interpret job insecurity not only at the national level but also in relation to the employees' company context. More international collaboration and numerical flexibility in the companies resulted in more pronounced job insecurity. Clear differences in job insecurity were found between company sizes, occupations, age groups, and gender. Our study thus contributes to extending research knowledge by explaining job insecurity in a company context as a consequence of selected management practices, namely, international collaboration and numerical flexibility. Although the overall level of job insecurity in our Danish sample is comparably low, we can identify the factors that challenge job insecurity, and we can illustrate variation between groups of employees, for example, employees in different occupations.

\section{Acknowledgments}

This research was financed by grant 20080053113/12-2008-09 from the Danish Working Environment Research Fund. 


\section{References}

Abell, P., Felin, T. \& Foss, N. (2008). Building micro-foundations for the routines, capabilities, and performance links, Managerial and Decision Economics 29(6): 489-502. doi: http://dx.doi.org/10.1002/mde.1413.

Anderson, C. J. \& Pontusson, J. (2007). Workers, worries and welfare states: social protection and job insecurity in 15 OECD countries, European Journal of Political Research 46(2): 211-235. doi: http://dx.doi.org/10.1111/j.1475-6765.2007.00692.x.

Archibugi, D. \& Michie, J. (1995). The globalisation of technology: a new taxonomy, Cambridge Journal of Economics 19(1): 121-140. doi: http://dx.doi.org/10.1093/oxfordjournals.cje.a035299.

Ashford, S. J., Lee, C. \& Bobko, P. (1989). Content, causes, and consequences of job insecurity: a theory-based measure and substantive test, The Academy of Management Journal 32(4): 803-829. doi: http://dx.doi.org/10.2307/256569.

Augier, M. \& Teece, D. J. (2008). Strategy as evolution with design: the foundations of dynamic capabilities and the role of managers in the economic system, Organization Studies 29(8-9): 1187-1208. doi: http://dx.doi.org/10.1177/0170840608094776.

Baillien, E. \& De Witte, H. (2009). Why is organizational change related to workplace bullying? Role conflict and job insecurity as mediators, Economic and Industrial Democracy 30(3): 348-371. doi: http://dx.doi.org/10.1177/0143831X09336557.

Banerjee, M., Tolbert, P. S. \& DiCiccio, T. (2012). Friend or Foe? The effects of contingent employees on standard employees' work attitudes, The International Journal of Human Resource Management 23(11): 2180-2204. doi: http://dx.doi.org/10.1080/09585192.2 011.637061.

Berglund, T., Furaker, B. \& Vulkan, P. (2014). Is job insecurity compensated for by employment and income security?, Economic and Industrial Democracy 35(1): 165-184. doi: http://dx.doi.org/10.1177/0143831X12468904.

Boxall P. \& Macky K. (2014). High-involvement work processes, work intensification and employee well-being, Work Employment Society 28(6): 963-984. doi: http://dx.doi. org/10.1177/0950017013512714.

Bredgaard, T., Larsen, F. \& Madsen, P. K. (2006). Opportunities and challenges for flexicurity The Danish example, Transfer: European Review of Labour and Research 12(1): 61-82. doi: http://dx.doi.org/10.1177/102425890601200107.

Bredgaard, T. \& Madsen, P. K. (2018). 'Farewell flexicurity? Danish flexicurity and the crisis' transfer, European Review of Labour and Research 24(4): 375-386. doi: http://dx.doi. org/10.117/1024258918768613.

Bruce, M., Leverick, F., Littler, D. \& Wilson, D. (1995). Success factors for collaborative product development: a study of suppliers of information and communication technology, R \& D Management 25(1): 33-44. doi: http://dx.doi.org/10.1177/102425890601200107.

Burchell, B., Ladipo, D. \& Wilkinson, F. (2001). Job Insecurity and Work Intensification, London: Routledge.

Burgoon, B. \& Dekker, F. (2010). Flexible employment, economic insecurity and social policy preferences in Europe, Journal of European Social Policy 20(2): 126-141. doi: http:// dx.doi.org/10.1177/0958928709358789.

Cegarra-Navarro, J. \& Dewhurst, F. (2007). Linking organizational learning and customer capital through an ambidexterity context: an empirical investigation in SMEs, The International Journal of Human Resource Management 18(10): 1720-1735. doi: http:// dx.doi.org/10.1080/09585190701570882.

Chung, H. \& van Oorschot, W. (2011). Institutions versus market forces: explaining the employment insecurity of European individuals during (the beginning of) the financial crisis, Journal of European Social Policy 21(4): 287-301. doi: http://dx.doi.org/10.1177/0958928711412224. 
Davis-Blake, A. \& Broschak, J. P. (2009). Outsourcing and the changing nature of work, Annual Review of Sociology 35(1): 321-340. doi: http://dx.doi.org/10.1146/annurev. soc.34.040507.134641.

Dill V. \& Jirjahn U. (2016). Foreign owners and perceived job insecurity in Germany: evidence from matched employer-employee data, International Journal of Manpower 37(8): 1286-1303. doi: http://dx.doi.org/10.1108/IJM-05-2015-0076.

Eisenhardt, K. M. \& Martin, J. A. (2000). Dynamic capabilities: what are they? Strategic Management Journal 21(10/11): 1105-1121. doi: http://dx.doi.org/10.1002/1097-0266 (200010/11)21:10/11<1105::AID-SMJ133>3.0.CO;2-E.

Ellonen, N. \& Nätti, J. (2015). Job insecurity and the unemployment rate: micros- and macrolevel predictors of perceived job insecurity among Finnish employees 1984-2008, Economic and Industrial Democracy 36(1): 51-71. doi: http://dx.doi.org/10.1177/ 0143831X13495720.

Felin, T., Foss, N. J. \& Ployhart, R. E. (2015). The microfoundations movement in strategy and organization theory, Academy of Management Annals 9(1): 575-632. doi: http:// dx.doi.org/10.1080/19416520.2015.1007651.

Gallie, D., Felstead,A., Green, F. \& Inanc,H. (2017). The hidden face of job insecurity, Work, Employment and Society 31(1): 36-53. doi: http://dx.doi.org/10.1177/0950017015624399.

Gjerding, A. N. (1997). The Flexible Firm: Transformation Pressure and Renewal in Danish Companies [Den fleksible virksomhed: omstillingspres og fornyelse i dansk erhvervsliv], København: Erhvervsfremme Styrelsen.

Green, F. (2001). It's been a hard day's night: the concentration and intensification of work in late twentieth-century Britain, British Journal of Industrial Relations 39(1): 53-80. doi: http://dx.doi.org/10.1111/1467-8543.00189.

Green, F. (2004). Why has work effort become more intense? Industrial Relations: A Journal of Economy and Society 43(4): 709-741. doi: http://dx.doi.org/10.1111/j.0019-8676. 2004.00359.x.

Hassard, J. \& Morris J. (2017). Corporate restructuring, work intensification and perceptual politics: Exploring the ambiguity of managerial job insecurity, Economic and Industrial Democracy, advance online publication. doi: http://dx.doi.org/10.1177/ $0143831 X 17710733$.

Hitt, M. A., Keats, B. W. \& DeMarie, S. M. (1998). Navigating in the new competitive landscape: building strategic flexibility and competitive advantage in the 21st century, Academy of Management Executive 12(4): 22-42. doi: http://dx.doi.org/10.5465/AME. 1998.1333922.

Hollanders, H. \& Es-Sadiki, N. (2013). Innovation Union Scoreboard 2013, Brussels: European Comission.

Hox, J. J. (2010). Multilevel Analysis. Techniques and Applications, New York: Routledge.

Jackson, S. E., Schuler, R. S. \& Jiang, K. (2014). An aspirational framework for strategic human resource management, The Academy of Management Annals 8: 1-56. doi: http:// dx.doi.org/10.1080/19416520.2014.872335.

Jensen, C. S. (2011). The flexibility of flexicurity: the Danish model reconsidered, Economic and Industrial Democracy 32(4): 721-737. doi: http://dx.doi.org/10.1177/0143831 $\underline{\mathrm{X} 11401928 .}$.

Jiang, L. \& Lavaysee, L. M. (2018). Cognitive and affective job insecurity: a meta-analysis and a primary study, Journal of Management 44(6): 2307-2342. doi: http://dx.doi. org/10.1177/0149206318773853.

Jiang, L. \& Probst, T. M. (2016). A multilevel examination of affective job insecurity climate on safety outcomes, Journal of Occupational Health Psychology 21(3): 366-377. doi: http://dx.doi.org/10.1037/ocp0000014.

Johnson, G., Scholes, K. \& Whittington, R. (2009). Fundamentals of Strategy, Harlow: Pearson. 
Keim, A. C., Landis, R. S., Pierce, C. A. \& Earnest, D. R. (2014). Why do employees worry about their jobs? A meta-analytic review of predictors of job insecurity, Journal of Occupational Health Psychology 19(3): 269-290. doi: http://dx.doi.org/10.1037/a0036743.

Kelliher, C. \& Anderson, D. (2010). Doing more with less? Flexible working practices and the intensification of work, Human Relations 63(1): 83-106. doi: http://dx.doi. org/10.1177/0018726709349199.

Lundvall, B. (2002). Innovation, Growth and Social Cohesion: The Danish Model (New Horizons in the Economics of Innovation), London: Edward Elgar Pub.

Maertz, C. P., Wiley, J. W., LeRouge, C. \& Campion, M. A. (2010). Downsizing effects on survivors: layoffs, offshoring, and outsourcing, Industrial Relations 49(2): 275-285. doi: http://dx.doi.org/10.1111/j.1468-232X.2009.00599.x.

Mastrostefano, M., Dijkstra, L. \& Poelman, H. (2009). Regions 2020. Globalisation Challenges for European Regions, Brussels: Directorate General for Regional Policy.

Mau, S., Mewes, J. \& Schöneck, N. M. (2012). What determines subjective socio-economic insecurity? Socio-economic Review 10(4): 655-682. doi: http://dx.doi.org/10.1093/ser/ mws001.

McCann, L., Hassard, J., \& Morris, J. (2010). Restructurig managerial labour in the USA, the UK and Japan: challenging the salience of 'varieties of capitalism', British Journal of Industrial Relations 48(2): 347-374. doi: http://dx.doi.org/10.1111/j.1467-8543.2010. 00794.x.

MEADOW consortium (2010). The MEADOW Guidelines, Grigny, France.

Mills, M. (2009). Globalization and inequality, European Sociological Review 25(1): 1-8. doi: http://dx.doi.org/10.1093/esr/jen046.

Näswall, K. \& De Witte, H. (2003). Who feels insecure in Europe? Predicting job insecurity from background variables, Economic and Industrial Democracy 24(2): 189-215. doi: http://dx.doi.org/10.1177/0143831X03024002003.

Nielsen, P., Lund, R., Lundvall, B., Gjerding, A. N., Nielsen, R. N., Rasmussen, J. G., Hesselholdt, A. D., Makó, C., Illéssy, M., Csizmadia, P., Härenstam, A., Bejerot, E., Som, O., Kirner, E., Huys, R., Lazaric, N. \& Coutts, A. (2008). Multi-Level Theoritical Framework MEADOW Background document ${ }^{\circ} 1$, Grigny, France: MEADOW consortium.

Nielsen, P., Nielsen, R. N., Bamberger, S. G., Stamhus, J., Fonager, K., Larsen, A., Vinding, A. L., Ryom, P. \& Omland, $\varnothing$ (2012). Capabilities for innovation: the nordic model and employee participation, Nordic Journal of Working Life Studies 2(4): 85-115. doi: http:// dx.doi.org/10.19154/njwls.v2i4.2306.

Nielsen, P. (2006). The Human Side of Innovation Systems: Innovation, Organizations and Competence Building in a Learning Perspective, Aalborg: Aalborg Universitetsforlag.

Nielsen, P. \& Lundvall, B. (2006). Learning organizations and industrial relations: how the Danish economy learns in How Europe's Economies Learn: Coordinating Competing Models, in B. Lundvall \& E. Lorenz (eds.), New York: Oxford University Press, pp. 161-177.

OECD (2016). Back to Work - Denmark - Improving the Re-employment Prospects of Displaced Workers, Paris: OECD.

Oreg, S., Vakola, M. \& Armenakis, A. (2011). Change recipients' reactions to organizational change, The Journal of Applied Behavioral Science 47(4): 461-524. doi: http://dx.doi. org/10.1177/0021886310396550.

Oreg, S. \& Sverdlik, N. (2011). Ambivalence toward imposed change: the conflict between dispositional resistance to change and the orientation toward the change agent, Journal of Applied Psychology 96(2): 337-349. doi: http://dx.doi.org/10.1037/a0021100.

Organisation for Economic Co-operation and Development \& Statistical Office of the European Communities (1997). Oslo manual: proposed guidelines for collecting and interpreting technological innovation data, Paris: Organisation for Economic Cooperation and Development. 
Pejtersen, J. H., Kristensen, T. S., Borg, V. \& Bjorner, J. B. (2010). The second version of the Copenhagen Psychosocial Questionnaire, Scandinavian Journal of Public Health 38(3 Suppl): 8-24. doi: http://dx.doi.org/10.1177/1403494809349858.

Peteraf, M.A. (1993). The cornerstones of competitive advantage. A resource-based view, Strategic Management Journal 14(3): 179-191. doi: http://dx.doi.org/10.1002/smj.4250140303.

Philips, K. \& Eamets, R. (2007). Impact of Globalisation on Industrial Relations in the EU and Other Major Economies, Luxembourg: Office for Official Publications of the European Communities.

Podsakoff, P. M., MacKenzie, S. B. \& Podsakoff, N. P. (2012). Sources of method bias in social science research and recommendations on how to control it, Annual Review of Psychology 63(1): 539-569. doi: http://dx.doi.org/10.1146/annurev-psych-120710-100452.

Probst, T. M. (2003). Exploring employee outcomes of organizational restructing: a Solomon four-group study., Group \& Organization Management 28(3): 416-439. doi: http://dx. doi.org/10.1177/1059601102250825.

Probst, T. M. \& Jiang, L. (2017). European flexicurity policies: multilevel effects on employee psychosocial reactions to job insecurity, Safety Science 100(part A): 83-90. doi: http:// dx.doi.org/10.1016/j.ssci.2017.03.010.

Quinlan, M. \& Bohle, P. (2009). Overstretched and unreciprocated commitment: reviewing research on the occupational health and safety effects of downsizing and job insecurity, International Journal of Health Services 39(1): 1-44. doi: http://dx.doi.org/10.2190/ HS.39.1.a.

Scheve, K. \& Slaughter, M. J. (2004). Economic insecurity and the globalization of production, American Journal of Political Science 48(4): 662-674. doi: http://dx.doi.org/10.1111/ j.0092-5853.2004.00094.x.

Schief, S. (2010). Does location matter? An empirical investigation of flexibility patterns in foreign and domestic companies in five European countries, The International Journal of Human Resource Management 21(1): 1-16. doi: http://dx.doi.org/10.1080/ 09585190903466830 .

Schilke, O., Hu, S. \& Helfat, C. E. (2018). Quo vadis, dynamic capabilities? A content-analytic review of the current state of knowledge and recommendations for future research, Academy of Management Annals 12(1): 390-439. doi: http://dx.doi.org/10.5465/annals. 2016.0014.

Scott, H. K. (2004). Reconceptualizing the nature and health consequences of work-related insecurity for the new economy: the decline of workers' power in the flexibility regime, International Journal of Health Services 34(1): 143-153. doi: http://dx.doi.org/10.2190/ WAM3-MNN2-6UNF-FDEX.

Shoss, M.K. (2017). Job insecurity: an integrative review and agenda for future research, Journal of Management 43(6): 1911-1939. doi: http://dx.doi.org/10.117/0149206317691574.

Sirmon, D. G., Hitt, M. A. \& Ireland, R. D. (2007). Managing firm resources in dynamic environments to create value: looking inside the black box, Academy of Management Review 32(1): 273-292. doi: http://dx.doi.org/10.5465/amr.2007.23466005.

Spiegel, J. M., Labonte, R. \& Ostry, A. S. (2004). Understanding 'globalization' as a determinant of health determinants: a critical perspective, International Journal of Occupational and Environmental Health 10(4): 360-367. doi: http://dx.doi.org/10.1179/oeh. 2004.10.4.360.

Standing, G. (1997). Globalization, labour flexibility and insecurity: the era of market regulation, European Journal of Industrial Relations 3(1): 7-37. doi: http://dx.doi.org/10.1177/ 095968019731002.

Statistics Denmark (2010). Statistical Yearbook 2010, Copenhagen: Statistics Denmark.

Teece, D. J. (2007). Explicating dynamic capabilities: the nature and microfoundations of (sustainable) enterprise performance, Strategic Management Journal 28(13): 1319-1350. doi: http://dx.doi.org/10.1002/smj.640. 
Teece, D. J., Pisano, G. \& Shuen, A. (1997). Dynamic capabilities and strategic management, Strategic Management Journal 18(7): 509-533. doi: http://dx.doi.org/10.1002/ (SICI) 1097-0266(199708)18:7<509::AID-SMJ882>3.0.CO;2-Z.

Timmermans, B. (2008). Documentation on the DISKO4-IDA merge and the creation of the panel dataset DISKO2-DISKO4, Department of Business Studies, Aalborg University.

Vander Elst, T., Baillien, E., De Witte, H. \& De Cuyper, N. (2010). The role of organizational communication and participation in reducing job insecurity and its negative association with work-related well-being, Economic and Industrial Democracy 31(2): 249-264. doi: http://dx.doi.org/10.1177/0143831X09358372.

Vinding, A. L. \& Drejer, I. (2006). The Further the Better? Knowledge Intensive Service Firms' Collaboration on Innovation, Aalborg: Danish Research Unit for Industrial Dynamics.

Vinding, A. L. \& Reichstein, T. (2003). Documentation of the IDA-DISKO Database, IKE Group Aalborg University, Aalborg University.

Wernerfelt, B. (1984). A resource-based view of the firm, Strategic Management Journal 5(2): 171-180. doi: http://dx.doi.org/10.1002/smj.4250050207.

Wright, P. M., Dunford, B. B. \& Snell, S. A. (2001). Human resources and the resource based view of the firm, Journal of Management 27(6): 701-721. doi: http://dx.doi. org/10.1177/014920630102700607.

Zaharia, C., Zaharia, G. C., Tudorescu, N. \& Zaharia, I. (2011). Effects of the global economic crisis on the market economy, Economics, Management and Financial Markets 6(2): 289-313. 